\title{
Restricting lignin and enhancing sugar deposition in secondary cell walls enhances monomeric sugar release after low temperature ionic liquid pretreatment
}

Chessa Scullin ${ }^{1,2}$, Alejandro G. Cruz ${ }^{1,3}$, Yi-De Chuang ${ }^{3}$, Blake A. Simmons ${ }^{1,2}$, Dominique Loque ${ }^{4,5}$ and Seema Singh 1,2,6* $^{*}$

\begin{abstract}
Background: Lignocellulosic biomass has the potential to be a major source of renewable sugar for biofuel production. Before enzymatic hydrolysis, biomass must first undergo a pretreatment step in order to be more susceptible to saccharification and generate high yields of fermentable sugars. Lignin, a complex, interlinked, phenolic polymer, associates with secondary cell wall polysaccharides, rendering them less accessible to enzymatic hydrolysis. Herein, we describe the analysis of engineered Arabidopsis lines where lignin biosynthesis was repressed in fiber tissues but retained in the vessels, and polysaccharide deposition was enhanced in fiber cells with little to no apparent negative impact on growth phenotype.
\end{abstract}

Results: Engineered Arabidopsis plants were treated with the ionic liquid (IL) 1-ethyl-3-methylimidazolium acetate 1-ethyl-3-methylimidazolium acetate $\left(\left[\mathrm{C}_{2} \mathrm{C}_{1}\right.\right.$ im] $\left.[\mathrm{OAC}]\right)$ at $10 \%$ wt biomass loading at either $70{ }^{\circ} \mathrm{C}$ for $5 \mathrm{~h}$ or $140{ }^{\circ} \mathrm{C}$ for $3 \mathrm{~h}$. After pretreatment at $140{ }^{\circ} \mathrm{C}$ and subsequent saccharification, the relative peak sugar recovery of $\sim 26.7 \mathrm{~g}$ sugar per $100 \mathrm{~g}$ biomass was not statistically different for the wild type than the peak recovery of $\sim 25.8 \mathrm{~g}$ sugar per $100 \mathrm{~g}$ biomass for the engineered plants (84 versus $86 \%$ glucose from the starting biomass). Reducing the pretreatment temperature to $70{ }^{\circ} \mathrm{C}$ for $5 \mathrm{~h}$ resulted in a significant reduction in the peak sugar recovery obtained from the wild type to $16.2 \mathrm{~g}$ sugar per $100 \mathrm{~g}$ biomass, whereas the engineered lines with reduced lignin content exhibit a higher peak sugar recovery of $27.3 \mathrm{~g}$ sugar per $100 \mathrm{~g}$ biomass and $79 \%$ glucose recoveries.

Conclusions: The engineered Arabidopsis lines generate high sugar yields after pretreatment at $70{ }^{\circ} \mathrm{C}$ for $5 \mathrm{~h}$ and subsequent saccharification, while the wild type exhibits a reduced sugar yield relative to those obtained after pretreatment at $140^{\circ} \mathrm{C}$. Our results demonstrate that employing cell wall engineering efforts to decrease the recalcitrance of lignocellulosic biomass has the potential to drastically reduce the energy required for effective pretreatment.

Keywords: Arabidopsis, Biofuels, Cell wall, Lignin, Saccharification, lonic liquid

\footnotetext{
* Correspondence: seesing@sandia.gov

'Deconstruction Division, Joint BioEnergy Institute, Lawrence Berkeley

National Laboratory, Berkeley, CA, USA

${ }^{2}$ Biological and Materials Science Center, Sandia National Laboratories,

Livermore, CA, USA

Full list of author information is available at the end of the article
} 


\section{Background}

Liquid transportation biofuels derived from sustainable lignocellulosic biomass have the potential to significantly reduce greenhouse gas emissions relative to petroleumderived fuels. While significant progress has been made in improving the economic viability and commercial scalability of renewable biofuels, there remain significant challenges that must be addressed before these processes reach their full potential [1-3]. These challenges include the relatively low energy density of the biomass feedstocks, the recalcitrance of the plant cell walls to enzymatic hydrolysis [1-3], and the current high cost of pretreatment required to reduce this recalcitrance [4]. Biomass pretreatments that use certain ionic liquids (ILs), such as 1-ethyl-3methylimidazolium acetate $\left(\left[\mathrm{C}_{2} \mathrm{C}_{1} \mathrm{im}\right][\mathrm{OAc}]\right)$, have been shown to help overcome biomass recalcitrance by increasing surface area and by partially or completely solubilizing the cell wall, decreasing cellulose crystallinity, increasing cellulose accessibility, and/or removing lignin [4-10]. One technique to monitor IL pretreatment is imaging the autofluorescence of biomass during IL pretreatment. These imaging studies have shown that a key step in biomass pretreatment using $\left[\mathrm{C}_{2} \mathrm{C}_{1} \mathrm{im}\right][\mathrm{OAc}]$ is cell wall swelling [9, 11]. The composition of the biomass and extent of delignification further affect biomass recalcitrance and saccharification kinetics [4, 6, 12-16]. Increasing the accumulation of polysaccharides in biomass and improving biomass digestibility would have significant beneficial impacts on the cost of lignocellulosic biofuel production, both by increasing fermentable sugar yield per acre and reducing the severity of pretreatment $[2,17]$.

The secondary cell walls in Arabidopsis are composed of cellulose (40\%), matrix polysaccharides ( 35\%) and lignin ( $20 \%$; primarily G and S units) [18-20]. Secondary cell walls are deposited on top of the primary cell wall in specific tissues (e.g., vessels and fibers) to provide rigidity and strength. Recently, a new approach using synthetic biology was developed in Arabidopsis to decrease lignin content in fibers while retaining its deposition in vessels $[21,22]$. In contrast to most approaches used to reduce lignin content [23-25], this one had no obvious impact on phenotype and plant growth. The engineering consisted of replacing the promoter controlling the expression of the second gene in the lignin pathway $(\mathrm{C} 4 \mathrm{H})$ that controls the metabolic flux of lignin biosynthesis via the vessel-specific promoter corresponding to the transcription factor VND6. This low lignin line was further engineered to enhance polysaccharide deposition in plant fiber cells using an artificial positive feedback loop technology that allows for the targeted overexpression of a key transcription factor, NST1, known to control secondary cell wall deposition in fibers $[21,26]$. The combination of both approaches resulted in decreased biomass recalcitrance that generated
Table 1 Initial compositional analysis for each Arabidopsis engineered line studied

\begin{tabular}{lllll}
\hline \multicolumn{4}{l}{ Untreated composition } & \\
\hline \% Glucose & \% Xylose & \% Lignin & $\%$ ASR \\
\hline WT & $26.1 \pm 0.1$ & $11.4 \pm 0.1$ & $19.1 \pm 0.3$ & $43.4 \pm 0.5$ \\
LLL & $23.0 \pm 0.7^{* *}$ & $10.8 \pm 0.2$ & $12.9 \pm 0.8^{* *}$ & $53 \pm 2^{* *}$ \\
LLHPL1 & $30.4 \pm 0.4^{* *}$ & $16.1 \pm 0.5^{* *}$ & $13.7 \pm 0.6^{* *}$ & $40 \pm 2$ \\
LLHPL2 & $22.1 \pm 0.5^{* *}$ & $11.7 \pm 0.1$ & $14 \pm 2^{* *}$ & $53 \pm 2^{* *}$ \\
\hline
\end{tabular}

There was an overall significant difference in the concentration of glucose, xylose, lignin, and ASR (acid soluble residue, ash, protein) $\mathrm{F}_{(3,12)}=150.87$, $P<0.0001, \mathrm{~F}_{(3,12)}=340.36, P<0.0001, \mathrm{~F}_{(3,12)}=28.65, P<0.0002, \mathrm{~F}_{(3,12)}=100.54$, $P<0.0001$. ANOVA with a Tukey's HSD post-hoc test was used to determine overall statistics, and results of the comparison to WT from the Tukey's HSD post-hoc test are shown in the table. Values expressed $\pm S D$

${ }^{* *} P<0.01$

higher yields of fermentable sugars on a per plant basis after hot water pretreatment followed by enzymatic hydrolysis [21].

To understand the full impact of these cell wall modifications on IL pretreatment, we investigated $\left[\mathrm{C}_{2} \mathrm{C}_{1} \mathrm{im}\right][\mathrm{OAc}]$ biomass pretreatment on one low lignin line $(L L L$, line \#135 in [21]) and two low lignin high polysaccharide lines (LLHPL1, line \#89 in [21] and LLHPL2, line \#60 in [21]). LLHPL1 and LLHPL2 were selected due to their different levels of polysaccharide accumulation [21]. The main objectives were to gain insight of the effect of cell wall modification on biomass deconstruction using ILs and to determine if the IL pretreatment process could be carried out at lower temperatures as a result of these modifications. We report the impact of these engineered lines relative to wild type (WT) in terms of pretreatment efficacy, sugar yields, and mass balances for IL pretreatment at 70 and $140{ }^{\circ} \mathrm{C}$

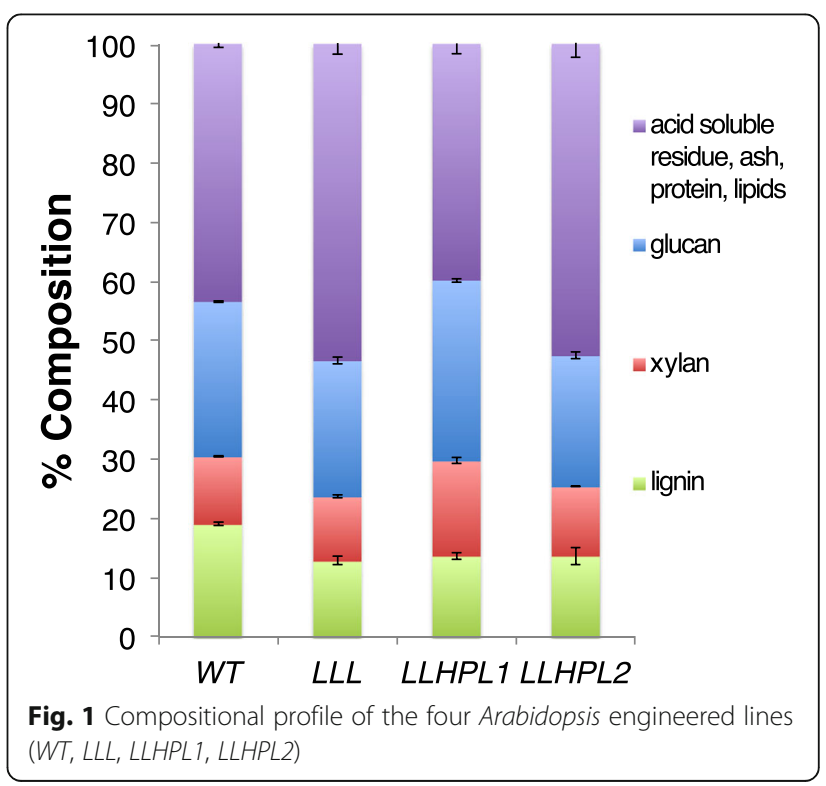




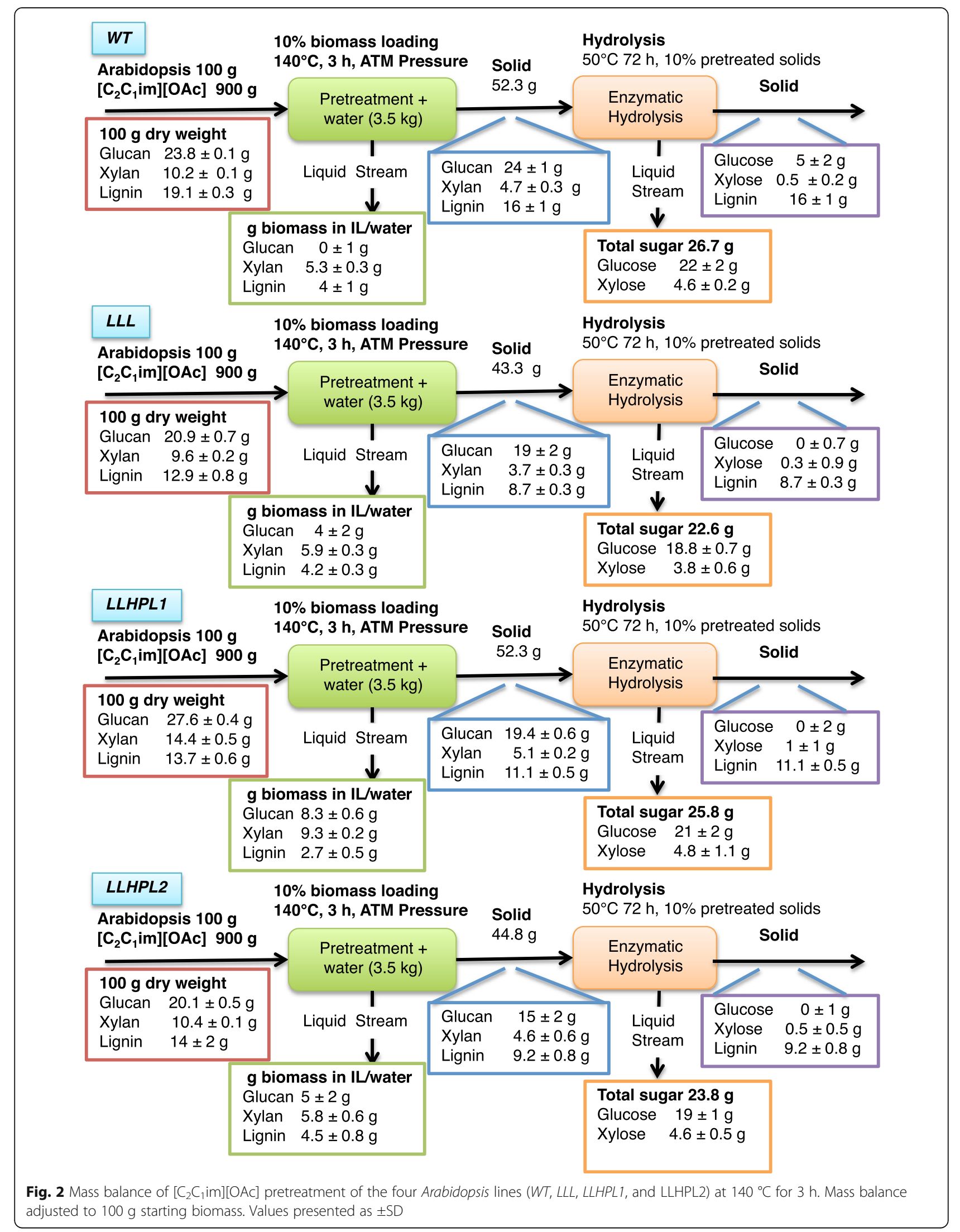


Table 2 Percent recovered solid composition after pretreatment at $140{ }^{\circ} \mathrm{C}$ for $3 \mathrm{~h}$ with $\left[\mathrm{C}_{2} \mathrm{C}_{1}\right.$ im] $[\mathrm{OAc}]$ at $10 \%(\mathrm{w} / \mathrm{w})$ biomass loading as a percent of starting biomass

\begin{tabular}{|c|c|c|c|c|}
\hline & \multicolumn{2}{|c|}{ Solids recovery } & \multirow{2}{*}{$\begin{array}{l}140{ }^{\circ} \mathrm{C} 3 \mathrm{~h} \\
\% \text { Lignin }\end{array}$} & \multirow[b]{2}{*}{$\%$ ASR } \\
\hline & $\%$ Glucose & $\%$ Xylose & & \\
\hline$W T$ & $101 \pm 6$ & $47 \pm 3$ & $82 \pm 5$ & $17 \pm 2$ \\
\hline LLL & $86 \pm 7$ & $39 \pm 3$ & $68 \pm 6$ & $23 \pm 1^{*}$ \\
\hline LLHPLI & $70 \pm 3^{* *}$ & $34 \pm 1^{*}$ & $81 \pm 14$ & $38 \pm 5^{* *}$ \\
\hline LLHPL2 & $74 \pm 10^{* *}$ & $44 \pm 6$ & $70 \pm 13$ & $28 \pm 3^{* *}$ \\
\hline
\end{tabular}

Pretreated solids composition $140{ }^{\circ} \mathrm{C}$ for $3 \mathrm{~h}$

$\begin{array}{lcccl} & \text { \% Total solids } & \text { \% Glucose } & \text { \% Xylose } & \% \text { Lignin } \\ \text { WT } & 52 \pm 3 & 51 \pm 1 & 10 \pm 2 & 30 \pm 2 \\ \text { LLL } & 43 \pm 4 & 46 \pm 2 & 10 \pm 2 & 20 \pm 2^{*} \\ \text { LLHPL1 } & 52 \pm 2 & 41 \pm 6 & 11 \pm 1 & 21 \pm 4^{* *} \\ \text { LLHPL2 } & 44 \pm 6 & 37 \pm 3 & 12 \pm 3 & 21 \pm 3^{* *}\end{array}$

All values presented as $\pm \mathrm{SD}$. There was an overall significant difference in $\%$ recovery of glucose, xylose, and ASR (acid soluble residue, ash, and protein) in the recovered solids, $F_{(3,12)}=12.86, P<0.002, F_{(3,12)}=7.37, P<0.01$ and $F_{(3,12)}=32.87$, $P<0.0001$. There was a non-significant difference in the lignin recovery in the solids, $\mathrm{F}_{(3,12)}=1.03, P=0.43$. Composition of recovered solids after pretreatment with [C2C1im] [OAc] for $140{ }^{\circ} \mathrm{C} 3 \mathrm{~h}$ at $10 \%(\mathrm{w} / \mathrm{w})$ biomass loading. Glucose, xylose, and lignin reported as a percent of recovered biomass $\pm S D$. There was an overall significant difference in \% total solids and lignin, $\mathrm{F}_{(3,12)}=5.08, P<0.05$, $\mathrm{F}_{(3,12)}=9.74, P<0.005$. There was no overall significance for the $\%$ composition glucose or xylose $\mathrm{F}_{(3,12)}=6.22, P=0.05, \mathrm{~F}_{(3,12)}=0.35$,

$P=0.79$. ANOVA with a Tukey's HSD post-hoc test was used to determine overall statistics, and results of the comparison to $W T$ from the post-hoc test are shown in the table

${ }^{*} P<0.05 ;{ }^{* *} P<0.01$ using $\left[\mathrm{C}_{2} \mathrm{C}_{1} \mathrm{im}\right][\mathrm{OAc}]$ followed by saccharification using commercially available enzyme mixtures.

\section{Results and discussion}

Mature, senesced stems (corresponding to the main stems and side branches depleted of seeds and cauline leaves) from multiple plants of the WT, LLL, LLHPL1, and LLHPL2 Arabidopsis lines grown under the same conditions were collected and milled, and the chemical composition was quantified. As previously reported, all the lines (LLL, LLHPL1, and LLHPL2) harboring the $p V N D 6:: C 4 H$ construct, exhibit a significantly lower lignin content (12.9 to $14 \%)$ compared to that of WT (19.1\%) and had no visible phenotypic differences (Table 1, Fig. 1) [21]. As expected, LLHPL1 shows an increase in the amount of both glucose $30.4 \%$ and xylose $16.1 \%$ present versus WT (26.1 and $11.4 \%$ respectively). The LLHPL2 showed only a minor increase in xylose, $11.7 \%$, for the bulk composition and a significant decrease in the amount of glucose present, $22.1 \%$, where previously it was found to have a significant increase on a per plant scale [21]. Both the LLL and LLHPL2 engineered Arabidopsis lines exhibit a significant increase in acid soluble residue (ASR), while LLHPL1 had an increase in glucose with little change in ASR compared to WT (Table 1).

We pretreated the $W T$ and the engineered strains with $\left[\mathrm{C}_{2} \mathrm{C}_{1} \mathrm{im}\right][\mathrm{OAc}]$ at $10 \%(\mathrm{w} / \mathrm{w})$ biomass loading at $140{ }^{\circ} \mathrm{C}$ for $3 \mathrm{~h}$ (Fig. 2) [8, 10, 27, 28]. The pretreated slurry was

Table 3 Enzymatic saccharification efficiency of Arabidopsis engineered line versus pretreatment condition

\begin{tabular}{|c|c|c|c|c|c|}
\hline \multicolumn{6}{|c|}{ Enzymatic saccharification $10 \%$ loading for $72 \mathrm{~h}$} \\
\hline & & $\%$ Glucose & $\%$ Xylose & $\%$ Glucose recovery & $\%$ Xylose recovery \\
\hline \multirow[t]{3}{*}{$\overline{W T}$} & Untreated & $31 \pm 3$ & $17 \pm 3$ & $31 \pm 3$ & $17 \pm 3$ \\
\hline & $10 \%, 70{ }^{\circ} \mathrm{C}, 5 \mathrm{~h}$ & $67 \pm 20$ & $1.0 \pm 0.3$ & $62 \pm 11$ & $1.0 \pm 0.2$ \\
\hline & $10 \%, 140{ }^{\circ} \mathrm{C}, 3 \mathrm{~h}$ & $84 \pm 6$ & $87 \pm 2$ & $84 \pm 1$ & $41 \pm 2$ \\
\hline \multirow[t]{3}{*}{ LLL } & Untreated & $46 \pm 4^{* *}$ & $33 \pm 1^{* *}$ & $46 \pm 4^{* *}$ & $33 \pm 1^{* *}$ \\
\hline & $10 \%, 70{ }^{\circ} \mathrm{C}, 5 \mathrm{~h}$ & $76 \pm 7$ & $46 \pm 5^{* *}$ & $76 \pm 5$ & $46 \pm 4^{* *}$ \\
\hline & $10 \%, 140{ }^{\circ} \mathrm{C}, 3 \mathrm{~h}$ & $95 \pm 4$ & $92 \pm 7$ & $82 \pm 4$ & $35 \pm 4^{* *}$ \\
\hline \multirow[t]{3}{*}{ LLHPL 1} & Untreated & $48.4 \pm 0.7^{* *}$ & $30.2 \pm 0.2^{* *}$ & $48 \pm 0.4^{* *}$ & $30 \pm 0.3^{* *}$ \\
\hline & $10 \%, 70{ }^{\circ} \mathrm{C}, 5 \mathrm{~h}$ & $79 \pm 4^{* *}$ & $58 \pm 3^{* *}$ & $63 \pm 4$ & $48 \pm 2^{* *}$ \\
\hline & $10 \%, 140{ }^{\circ} \mathrm{C}, 3 \mathrm{~h}$ & $99 \pm 7^{*}$ & $83 \pm 9$ & $69 \pm 3^{*}$ & $30 \pm 3$ \\
\hline \multirow[t]{3}{*}{ LLHPL2 } & Untreated & $53 \pm 3^{* *}$ & $31 \pm 1^{* *}$ & $53 \pm 3^{* *}$ & $31 \pm 1^{* *}$ \\
\hline & $10 \%, 70{ }^{\circ} \mathrm{C}, 5 \mathrm{~h}$ & $81 \pm 4^{* *}$ & $55 \pm 5^{* *}$ & $79 \pm 1^{*}$ & $58 \pm 1^{* *}$ \\
\hline & $10 \%, 140{ }^{\circ} \mathrm{C}, 3 \mathrm{~h}$ & $117 \pm 6^{* *}$ & $89 \pm 6$ & $87 \pm 8$ & $39 \pm 2$ \\
\hline
\end{tabular}

Enzymatic saccharification efficiency reported as percent of theoretical in the saccharification (released as percent from pretreated biomass) and final recovery \% from concentration in initial solids (sugar recovery * enzymatic efficiency), from the cellulose and hemicellulose mixtures CTec2 and HTec2 ( $20 \mathrm{mg} / \mathrm{g}$ and $2 \mathrm{mg} / \mathrm{g}$ loading for $72 \mathrm{~h}$ ). All values presented as \pm SD. There was an overall significant difference of the \% glucose and xylose released from untreated biomass during enzymatic saccharification between the $W T$ and the three engineered lines, $F_{(3,12)}=30.59, P<0.0001, F_{(3,12)}=66.83, P<0.0001, x y l o s e$ for the $70{ }^{\circ} \mathrm{C}$ pretreated biomass, $F_{(3,12)}=139.36, P<0.0001$, and glucose for the $140{ }^{\circ} \mathrm{C}$ pretreated biomass, $F_{(3,12)}=18.57, P<0.001$. There was a non-significant differences for the \% saccharification efficiency for glucose for the $70{ }^{\circ} \mathrm{C}$ pretreatment $F_{(3,12)}=0.95, P=0.46$ and for xylose for the $140{ }^{\circ} \mathrm{C}$ pretreatment $F_{(3,12)}=0.85, P=0.50$. There were significant differences both the glucose and xylose recoveries at each pretreatment condition, untreated $\left(\mathrm{F}_{(3,12)}=30.6, P<0.0001, \mathrm{~F}_{(3,12)}=66.8, P<0.0001\right)$, $70{ }^{\circ} \mathrm{C}\left(\mathrm{F}_{(3,12)}=4.35, P<0.05 \mathrm{~F}_{(3,12)}=355.29, P<0.0001\right)$ and $140{ }^{\circ} \mathrm{C}\left(\mathrm{F}_{(3,12)}=7.93, P<0.01, \mathrm{~F}_{(3,12)}=9.38, P<0.01\right)$. ANOVA with a Tukey's HSD post-hoc test was used to determine overall statistics, and results of the comparison to WT from the post-hoc test are shown in the table ${ }^{*} P<0.05 ;{ }^{* *} P<0.01$ 
washed with water as an anti-solvent, precipitating a solid. The lignin concentrations of the pretreated solids from the reduced lignin lines were confirmed to be significantly lower than WT ( 20\% lignin in the engineered lines and $\sim 30 \%$ lignin in the $W T$, Table 2) with insignificant differences in the amount of glucose and xylose removed for the engineered lines (Table 2). The $W T$ had a significantly higher glucan recovery in the after IL pretreatment, as compared to the engineered lines where glucan recoveries of 86,70 , and $74 \%$ were quantified for $L L L, L L H P L 1$, and LLHPL2, respectively. Less than $50 \%$ of xylan was recovered in the solids after pretreatment for all of the Arabidopsis lines tested (Table 2), and all three of the reduced lignin lines had a significant increase in ASR in the recovered biomass after IL pretreatment as compared to the WT (Table 2).

The recovered solids from the Arabidopsis lines after $\left[\mathrm{C}_{2} \mathrm{C}_{1} \mathrm{im}\right][\mathrm{OAc}]$ pretreatment were then saccharified using a commercial cellulase (CTec2) and hemicellulase (HTec2) enzyme mixture [10]. The yields of glucan after saccharification for LLL, LLHPL1, and LLHPL2 were >95\% and significantly higher than those obtained from samples with no pretreatment (Table 3). There was no difference in the saccharification efficiency for xylan yields between the

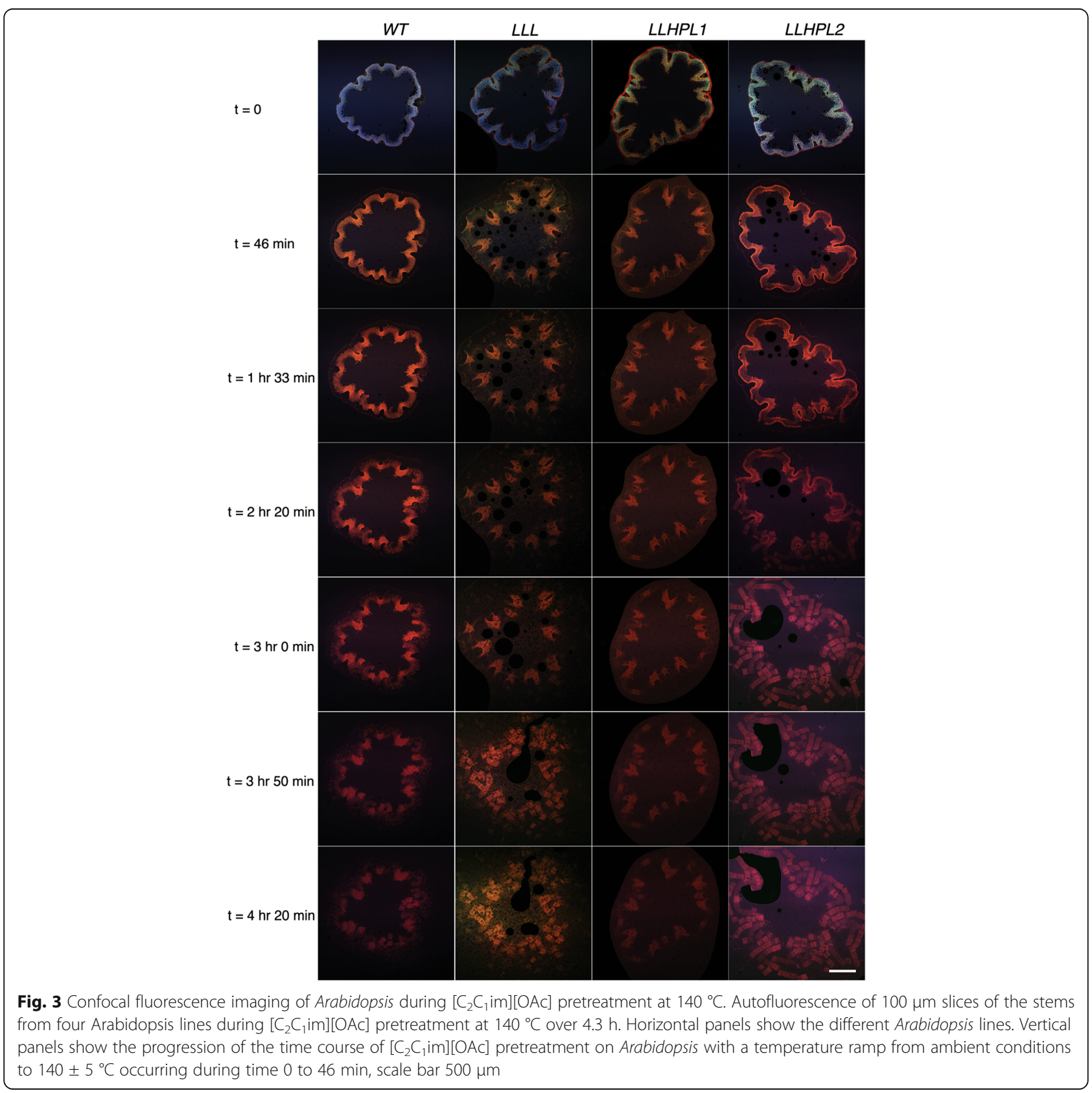


three modified plant lines. This resulted in final glucose yields of 69 to $87 \%$ recovery in terms of the initial amount present in the samples before pretreatment. These glucose yields were not significantly different between the WT, $L L L$, and LLHPL2 samples but were significantly lower for glucose and xylose released from LLHPL1 compared to the $W T$, as well as xylose released from the $L L L$ sample (Table 3, Fig. 2).

All of the Arabidopsis samples were observed to swell during IL pretreatment at $140{ }^{\circ} \mathrm{C}$ for $3 \mathrm{~h}$ (see Additional files 1,2, 3, and 4: Movies 1-4). The observed rate of dissolution due to $\left[\mathrm{C}_{2} \mathrm{C}_{1} \mathrm{im}\right][\mathrm{OAc}]$ pretreatment, however, was slower for the $W T$ than the engineered lines (Fig. 3, Additional file 5: Figure S1). Due to the relatively minor differences observed in the rate and extent of dissolution at $140{ }^{\circ} \mathrm{C}$, the temperature was reduced to $70{ }^{\circ} \mathrm{C}$ to determine if there were any significant differences observed in swelling and dissolution between the $W T$ and LLHPL2. At this set of pretreatment conditions, there was an initial swelling step observed after $1 \mathrm{~h}$ of pretreatment, followed by the onset of extensive swelling after 3-4.5 h (Additional file 6: Figure S2, Additional files 7 and 8: Movie 5 and 6). Based on these results, a pretreatment incubation of $5 \mathrm{~h}$ at $70{ }^{\circ} \mathrm{C}$ was selected as the new pretreatment condition (Fig. 4).

The Arabidopsis lines WT, LLL, LLHPL1, and LLHPL2 were pretreated in $\left[\mathrm{C}_{2} \mathrm{C}_{1} \mathrm{im}\right][\mathrm{OAc}]$ at $70{ }^{\circ} \mathrm{C}$ for $5 \mathrm{~h}$. The pretreated plant biomass was then precipitated and analyzed for composition (Fig. 5, Table 4). All of the lines had significantly lower solid recoveries (70.7 to $80.6 \%$ ) than those of the WT (96\%, Table 4), yet the three engineered lines had similar glucose and xylose recoveries in the pretreated solids as the WT (WT >94\% glucose, $>106 \%$ xylose, relative to initial biomass, Table 4). Furthermore, all of the Arabidopsis lines had minimal lignin removal (between 3 to $11 \%$ ) after pretreatment (Table 4).

The recovered solids from the different Arabidopsis lines after $\left[\mathrm{C}_{2} \mathrm{C}_{1} \mathrm{im}\right][\mathrm{OAc}]$ pretreatment at $70{ }^{\circ} \mathrm{C}$ for $5 \mathrm{~h}$ were then saccharified. While there was less than $11 \%$ removal of lignin, glucose yields of 76,79 , and $81 \%$ were obtained for LLL, LLHPL1, and LLHPL2, respectively, and the saccharification efficiency was significantly greater for LLHPL1 and LLHPL2 than that of WT $(67 \%$, Table 3). The resulting release of glucose relative to initial levels in the biomass was $62 \%$ of the initial glucose for the WT, $76 \%$ for the $L L L, 63 \%$ for the LLHPL1, and $79 \%$ for the LLHPL2 (Table 3, Fig. 5). There was minimal detectable xylose released (1\%) during saccharification for the WT; however, the three engineered lines had a significantly higher xylose yields of 46 to $58 \%$. In addition to the high recovery of glucose (63-79\%) and xylose (46-58 \%) at the lower pretreatment temperature, the enhanced concentration of cellulose and hemicellulose

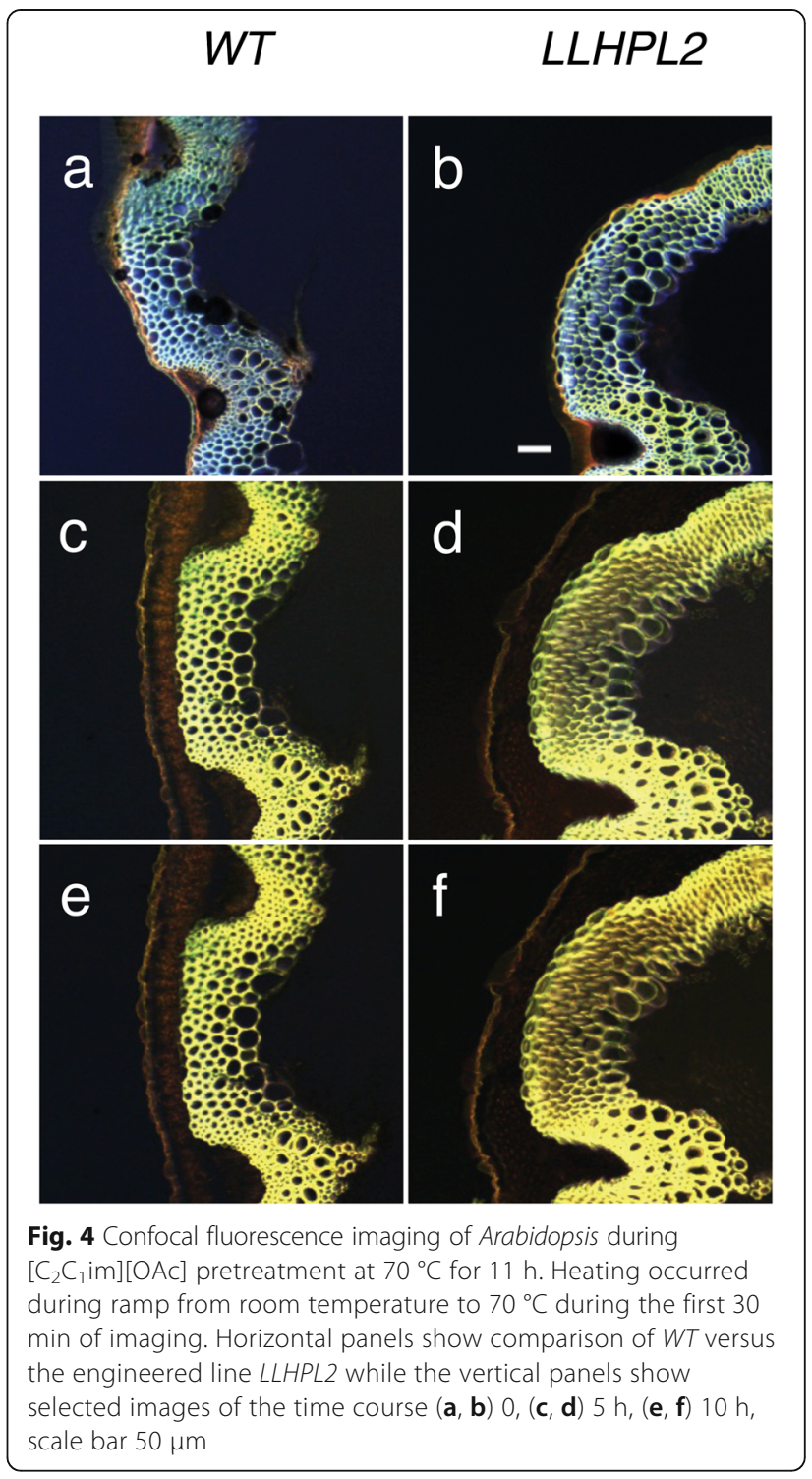

per gram of starting biomass resulted in higher monomeric sugar release in all of the engineered lines (Figs. 2, 5, and 6). Both LLHPL1 and LLHPL2 have significantly increased total sugar recovery (27.3 and $24.2 \mathrm{~g}$ total sugar per $100 \mathrm{~g}$ starting biomass) as compared to the $16.2 \mathrm{~g}$ total sugar per $100 \mathrm{~g}$ starting biomass of the WT (Fig. 6, Additional file 9: Tables S1 and S2).

While there are similar recoveries and enhanced total sugar release, the saccharification kinetics are slower for the biomass pretreated at $70{ }^{\circ} \mathrm{C}$ than those pretreated at $140{ }^{\circ} \mathrm{C}$ (Table 5). After pretreatment at $70{ }^{\circ} \mathrm{C}$ for $5 \mathrm{~h}$, the initial rate of glucose release for the $W T$ was $86 \mathrm{mg} / \mathrm{L} /$ $\mathrm{min}$, and the rates for the three engineered lines were between 40 to $52 \mathrm{mg} / \mathrm{L} / \mathrm{min}$. The rate of xylose release was below the detectable limit for $W T$, while the initial rate of release for xylose was significantly higher, 


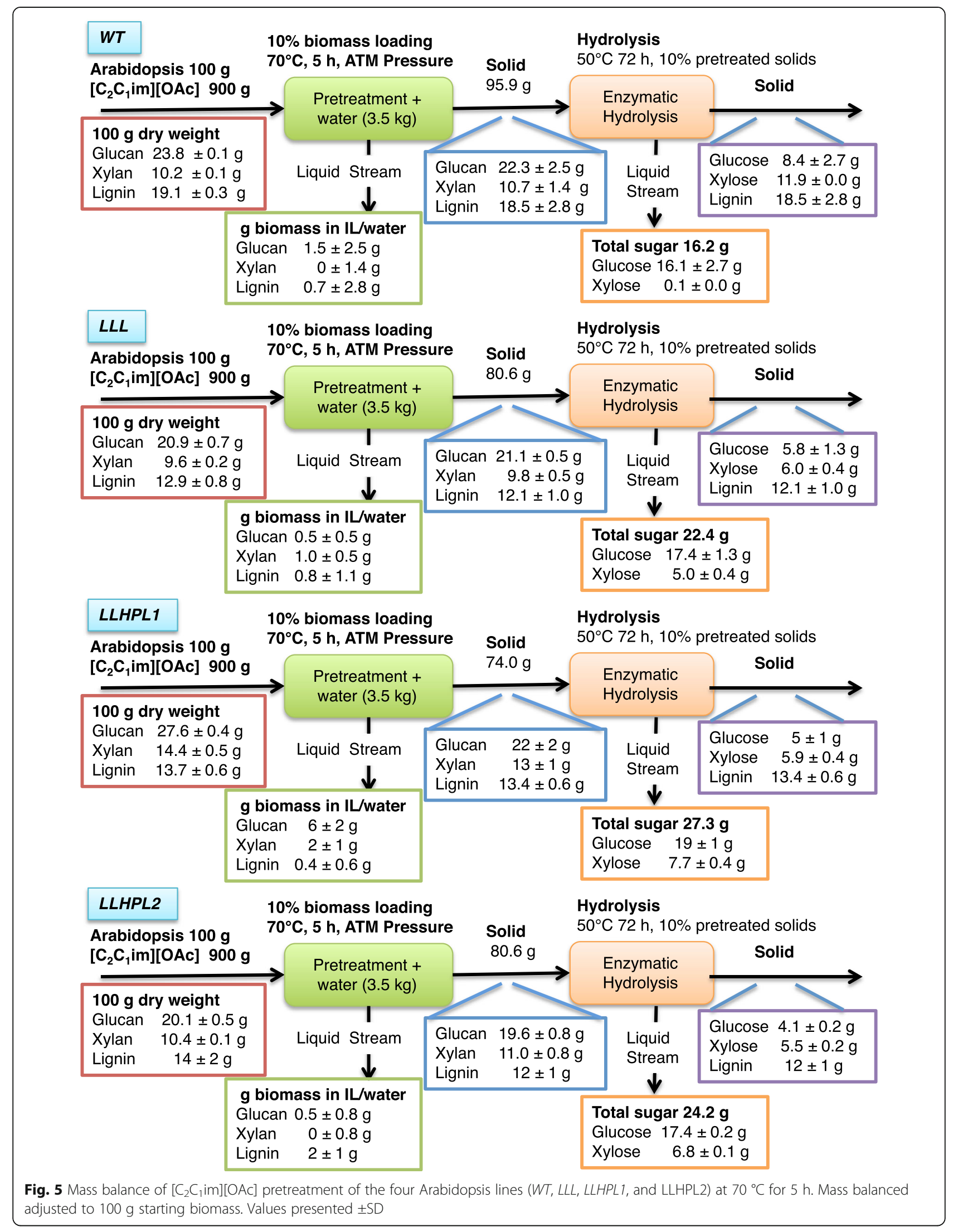


Table 4 Percent recovered solid composition after pretreatment at $70{ }^{\circ} \mathrm{C}$ for $5 \mathrm{~h}$ with $\left[\mathrm{C}_{2} \mathrm{C}_{1}\right.$ im] [OAc] at $10 \%(\mathrm{w} / \mathrm{w})$ biomass loading as a percent of starting biomass

Pretreated biomass solids recovery $70{ }^{\circ} \mathrm{C} 5 \mathrm{~h}$

$\begin{array}{lcccc} & \text { \% Glucose } & \text { \% Xylose } & \text { \% Lignin } & \% \text { ASR } \\ \text { WT } & 94 \pm 10 & 106 \pm 14 & 97 \pm 15 & 94 \pm 20 \\ \text { LLL } & 101 \pm 2 & 102 \pm 5 & 94 \pm 8 & 66 \pm 10 \\ \text { LLHPL1 } & 80 \pm 10 & 84 \pm 8 & 97 \pm 5 & 59 \pm 20 \\ \text { LLHPL2 } & 98 \pm 4 & 106 \pm 8 & 89 \pm 7 & 50 \pm 3^{*}\end{array}$

Pretreated biomass composition $70{ }^{\circ} \mathrm{C} 5 \mathrm{~h}$

$\begin{array}{lcccc} & \text { \% Total solids } & \text { \% Glucose } & \text { \% Xylose } & \text { \% Lignin } \\ \text { WT } & 96 \pm 10 & 26 \pm 4 & 13 \pm 2 & 19 \pm 3 \\ \text { LLL } & 80.6 \pm 0.9^{* *} & 31 \pm 1 & 13.7 \pm 0.7 & 15 \pm 2 \\ \text { LLHPL1 } & 74 \pm 1^{*} & 33 \pm 4 & 19 \pm 2^{*} & 18.1 \pm 0.9 \\ \text { LLHPL2 } & 70.7 \pm 0.7^{*} & 29 \pm 2 & 17 \pm 1^{*} & 17 \pm 1\end{array}$

Values presented as \pm SD. There was an overall significant difference in $\%$ recovery of glucose and ASR (acid soluble residue, ash, and protein) in the recovered solids, $F_{(3,12)}=5.01, P<0.03$ and $F_{(3,12)}=4.07, P<0.05$. There was a non-significant difference in the $\%$ xylose and lignin recovery in the solids, $\mathrm{F}_{(3,12)}=3.89, P=0.06$ and $\mathrm{F}_{(3,12)}=0.44, P=0.73$. Composition of recovered solids after $70{ }^{\circ} \mathrm{C} 5 \mathrm{~h}[\mathrm{C} 2 \mathrm{C} 1 \mathrm{im}][\mathrm{OAc}]$ pretreatment. Glucose, xylose, and lignin were reported as the relative composition of recovered biomass. Pretreatment was done at $10 \%(\mathrm{w} / \mathrm{w})$ biomass. There was an overall significant difference in $\%$ total solids and xylose, $\mathrm{F}_{(3,12)}=11.52, P<0.005, \mathrm{~F}_{(3,12)}=8.48, P<0.01$. There was no overall significance for the \% composition glucose or lignin $\mathrm{F}_{(3,12)}=2.57$, $P=0.13$ and $\mathrm{F}_{(3,12)}=3.1, P=0.09$. ANOVA with a Tukey's HSD post-hoc test was used to determine overall statistics, and results of the comparison to $W T$ from the post-hoc test are shown in the table

" $P<0.05 ;{ }^{* * *} P<0.01$

between 46 to $68 \mathrm{mg} / \mathrm{L} / \mathrm{min}$, for the engineered lines. As the composition of both LLHPL1 and LLHPL2 are different, so were the rates of sugar released during saccharification. $\left[\mathrm{C}_{2} \mathrm{C}_{1} \mathrm{im}\right][\mathrm{OAc}]$ pretreatment at $70{ }^{\circ} \mathrm{C}$ for 3 days has been shown previously to release less sugar than pretreatment at $140{ }^{\circ} \mathrm{C}$ for $3 \mathrm{~h}$ [29]. The reduced lignin Arabidopsis lines, however, all show increased sugar release after pretreatment at $70{ }^{\circ} \mathrm{C}$, highlighting the impact of plant cell wall modifications on pretreatment severity and related energy requirements.

\section{Conclusion}

The impact of engineering secondary cell wall structure in Arabidopsis with a selective reduction of lignin and an enhancement of cellulose accumulation was evaluated in terms of pretreatment efficacy, sugar yields, and energy requirements. The reduced lignin Arabidopsis engineered lines resulted in high levels of monomeric sugar release at lower pretreatment temperatures as compared to the wild type. Ionic liquid pretreatment of the engineered Arabidopsis using $\left[\mathrm{C}_{2} \mathrm{C}_{1} \mathrm{im}\right][\mathrm{OAc}]$ at $70{ }^{\circ} \mathrm{C}$ for $5 \mathrm{~h}$ resulted in improved saccharification efficiency and increased hemicellulose recovery for the pretreated biomass and produced similar total sugar yields as compared to those obtained after pretreatment at $140{ }^{\circ} \mathrm{C}$ for $3 \mathrm{~h}$. The similar sugar recovery obtained for the engineered lines at the lower temperature pretreatment supports the hypothesis that reducing lignin can reduce the necessary severity of pretreatment needed and increased polysaccharide deposition can increase glucose recovery on a mass basis.

Secondary cell wall regulatory networks are only partially understood and seem to be conserved across many species from dicot to monocot plants [30-32]. For example, an Arabidopsis nst1/nst3 double T-DNA insertional mutant lacking expression of both NST1 and NST3 transcription factors that control secondary cell wall deposition in fiber cells could be complemented by the expression of NST1 transcription factor orthologs derived from poplar or rice under the control of the Arabidopsis NST1 promoter [33,34]. This had an effect on the ASR amounts between the engineered lines, which could be important for pretreatment and sugar recovery. This suggests that a similar approach for cell wall engineering could be implemented into other vascular plant species to enhance polysaccharide deposition in secondary cell walls. The different levels of sugar recovery between LLHPL1 and LLHPL2 demand further investigations into the optimal expression levels and patterns of C4H and NST1. Using this selective strategy to reduce lignin deposition and enhance carbohydrate composition of specific cellular structures in a more diverse group of vascular plants could create higher yielding feedstocks that require less energy to process, thereby, improving the overall economics of biofuel production.

\section{Methods}

\section{Plant biomass}

Wild type Arabidopsis thaliana (ecotype Columbia) and the three engineered lines named $L L L, L L H P L 1$, and LLHPL2 correspond to $c 4 h+p V N D 6:: C 4 H, c 4 h+$ pVND6::C4H-pIRX8::NST1 line \# 89 and line \# 60, respectively, in Yang et al. [21]. The wild type Arabidopsis ecotype Col0 (WT) is our reference plant. The $p V N D 6:: C 4 H$ gene construct was used to complement the Arabidopsis c4h lignin mutant (ref3-2) $[35,36]$ and correspond to replacing the promoter for the second gene $(\mathrm{C} 4 \mathrm{H})$ in the lignin synthesis pathway with a promoter that is primarily expressed in vessel cells. This $L L L$ plant line (c4h lignin mutant harboring the $p V N D 6:: C 4 H$ gene construct) was further engineered with pIRX8::NST1 construct [21] corresponding to the artificial positive feedback loop to increase secondary cell wall polysaccharide deposition. Two independent lines were generated [21] and were named LLHPL1 and LLHPL2 in this study. The lines LLHPL1 and LLHPL2 have been previously characterized, while having the same constructs, they have unique pIRX8::NST1 construct insertion sites resulting in compositional differences on a per plant basis [21]. 


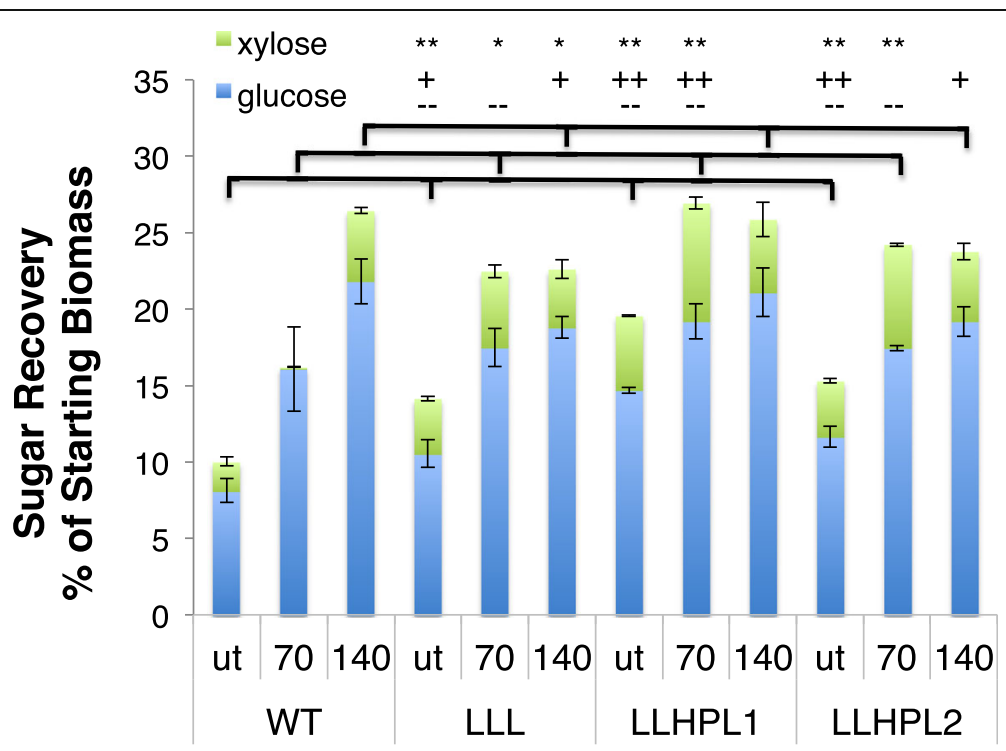

Fig. 6 Comparison of glucose and xylose recovery after enzymatic saccharification as a percent of original biomass for $\left[\mathrm{C}_{2} \mathrm{C}_{1}\right.$ im] $[\mathrm{O} A \mathrm{Ac}]$ pretreatment. Glucose and xylose recovery after $70{ }^{\circ} \mathrm{C}$ for $5 \mathrm{~h}$ and $140{ }^{\circ} \mathrm{C}$ for $3 \mathrm{~h}$ compared to the untreated (ut) for all of the Arabidopsis lines. There was an significant difference in total sugar released per starting biomass between the Arabidopsis lines at each pretreatment temperature, untreated $\left(F_{(3,12)}=72.44, P<0.0001\right), 70{ }^{\circ} \mathrm{C}\left(F_{(3,12)}=19.45, P<0.0005\right)$, and $140{ }^{\circ} \mathrm{C}\left(F_{(3,12)}=5.86, P<0.05\right)$. This was in part due to significant differences between groups in glucose recovery per starting biomass for all three pretreatment conditions untreated $\left(F_{(3,12)}=47.2, P<0.0001\right)$, $70^{\circ} \mathrm{C}\left(F_{(3,12)}=7.86, P<0.01\right)$, and $140^{\circ} \mathrm{C}\left(F_{(3,12)}=6.62, P<0.01\right)$. There was also significant difference in xylose recovery per starting biomass between the lines for two of the three pretreatment conditions untreated $\left(F_{(3,12)}=134.12, P<0.0001\right)$ and $70{ }^{\circ} \mathrm{C}\left(F_{(3,12)}=404.71, P<0.0001\right)$. There was not a significant difference in xylose release per starting biomass at $140^{\circ} \mathrm{C}\left(F_{(3,12)}=3.43, P=0.07\right)$. ANOVA with a Tukey's HSD post-hoc test and the Tukey's HSD post-hoc test are shown in the figure for the comparison to WT (total sugar, $P<0.05,{ }^{*} ; P<0.01$, ${ }^{* *}$; glucose, $P<0.05,+; P<0.01,++; x y l o s e, P<0.05,-; P<0.01,-$ ), additional post-hoc test comparisons reported in Additional file 9: Table $\$ 1$ and $\$ 2$

Arabidopsis plants were grown in soil under short-day conditions for 5 weeks (10 h:14 h/light:dark cycle) before being transferred to long-day growth conditions (14 h:10 $\mathrm{h} /$ light:dark cycle) until mature at $150 \mu \mathrm{mol} / \mathrm{m}^{2} / \mathrm{s}, 22{ }^{\circ} \mathrm{C}$, and $60 \%$ humidity. The Arabidopsis main stems and side branches depleted of seeds and cauline leaves were pooled and milled to 40 mesh $(0.255-0.451 \mathrm{~mm})$ by a Wiley mill. All experiments were done in triplicate from different samples of the milled biomass.

\section{IL pretreatment}

1-ethyl-3-methylimidazolium acetate, $\left[\mathrm{C}_{2} \mathrm{C}_{1} \mathrm{im}\right][\mathrm{OAc}]$, was purchased from BASF (lot no. 08-0010, purity >95\%, BasionicsTM BC-01, BASF, Florham Park, NJ, USA) and used as the IL for all pretreatments. The Arabidopsis was stored at $4{ }^{\circ} \mathrm{C}$ in a cold room before use. Arabidopsis was pretreated with $\left[\mathrm{C}_{2} \mathrm{C}_{1} \mathrm{im}\right][\mathrm{OAc}]$ at both $70{ }^{\circ} \mathrm{C}$ for $5 \mathrm{~h}$ and $140{ }^{\circ} \mathrm{C}$ for $3 \mathrm{~h}$ using a previously published protocol $[8,10]$. Biomass loading in $\left[\mathrm{C}_{2} \mathrm{C}_{1} \mathrm{im}\right][\mathrm{OAc}]$ was $10 \%$ $(\mathrm{w} / \mathrm{w})$ with $2 \mathrm{~g}$ of starting biomass for each replicate.

After pretreatment, the samples were thoroughly mixed, and hot water as an anti-solvent was added at 3.5 times the initial total mass (of both biomass and IL) to recover any solubilized biomass. The mixture of IL, water, and biomass was centrifuged to separate the solid (biomass) and liquid $\left(\left[\mathrm{C}_{2} \mathrm{C}_{1} \mathrm{im}\right][\mathrm{OAc}]\right.$ and water) phases. The recovered solid was lyophilized (Labconco FreeZone ${ }^{(12)}$, Kansas City, MO, USA) and used for analysis.

\section{Compositional analysis \\ Total sugar analysis}

Structural carbohydrates (including glucan and xylan) of Arabidopsis, before and after pretreatment (Tables 1, 2, and 4), were determined according to the two-step acid hydrolysis procedure of the National Renewable Energy Laboratory (NREL) [37]. Carbohydrates were diluted 100 fold and analyzed by HPLC. All values are reported \pm one standard deviation (SD) unless noted.

\section{Lignin analysis}

Acid insoluble lignin content of the untreated and pretreated Arabidopsis samples was determined using the two-step acid hydrolysis procedure of the National Renewable Energy Laboratory (NREL) [37]. All values are given with SD unless noted.

\section{Enzymatic saccharification}

Enzymatic saccharification of pretreated and untreated Arabidopsis samples was carried out at $50{ }^{\circ} \mathrm{C}$ and 150 rpm in a reciprocating shaker (Enviro-Genie, Scientific 
Table 5 Rate of enzymatic saccharification as calculated by release during the first 30 min of enzymatic hydrolysis with both the cellulase and hemicellulase mixtures $\mathrm{CTec} 2$ and $\mathrm{HTec} 2$

\begin{tabular}{llll}
\hline & \multicolumn{3}{l}{ Rate of enzymatic saccharification $10 \%$ loading at $72 \mathrm{~h}$} \\
\cline { 2 - 4 } & & $\begin{array}{l}\text { Rate glucose } \\
\text { (mg/L/min) }\end{array}$ & $\begin{array}{l}\text { Rate xylose } \\
\text { (mg/L/min) }\end{array}$ \\
\hline WT & Untreated & $43 \pm 2$ & $51 \pm 10$ \\
& $10 \% 70{ }^{\circ} \mathrm{C}, 5 \mathrm{~h}$ & $86 \pm 16$ & n.d. \\
& $10 \% 140{ }^{\circ} \mathrm{C}, 3 \mathrm{~h}$ & $196 \pm 7$ & $96 \pm 42$ \\
LLL & Untreated & $30 \pm 0.5$ & $41 \pm 7$ \\
& $10 \% 70{ }^{\circ} \mathrm{C}, 5 \mathrm{~h}$ & $41 \pm 7^{*}$ & $46 \pm 1^{* *}$ \\
& $10 \% 140{ }^{\circ} \mathrm{C}, 3 \mathrm{~h}$ & $255 \pm 10^{*}$ & $154 \pm 33$ \\
LLHPL1 & Untreated & $54 \pm 7$ & $58 \pm 20$ \\
& $10 \% 70{ }^{\circ} \mathrm{C}, 5 \mathrm{~h}$ & $52 \pm 8^{*}$ & $68 \pm 9^{* *}$ \\
& $10 \% 140{ }^{\circ} \mathrm{C}, 3 \mathrm{~h}$ & $271 \pm 13^{*}$ & $221 \pm 16^{*}$ \\
LLHPL2 & Untreated & $19 \pm 10$ & $41 \pm 20$ \\
& $10 \% 70{ }^{\circ} \mathrm{C}, 5 \mathrm{~h}$ & $40 \pm 16^{* *}$ & $62 \pm 13^{* *}$ \\
& $10 \% 140{ }^{\circ} \mathrm{C}, 3 \mathrm{~h}$ & $221 \pm 16$ & $146 \pm 50$ \\
\hline
\end{tabular}

Values presented \pm SD. There were significant differences between Arabidopsis lines for both the initial glucose and xylose rates for solids pretreated at $70{ }^{\circ} \mathrm{C}$ (glucose, $\mathrm{F}_{(3,12)}=8.8, P<0.01$ and xylose, $\mathrm{F}_{(3,12)}=43.6, P<0.0001$ ), and solids pretreated at $140{ }^{\circ} \mathrm{C}$ (glucose, $F_{(3,12)}=7.35, P<0.05$ and xylose, $F_{(3,12)}=5.66$, $P<0.05)$. There was no significant difference of initial rate of xylose release between the groups in untreated (xylose, $F_{(3,12)}=0.62, P=0.62$ ), but there was a significant difference between groups for initial rate of glucose release (glucose, $\left.\mathrm{F}_{(3,12)}=11.22, P<0.05\right)$. ANOVA with a Tukey's HSD post-hoc test was used to determine overall statistics, and results of the comparison to WT from the post-hoc test are shown in the table n.d. not detectable

${ }^{*} P<0.05 ;{ }^{* *} P<0.01$

Industries). Hydrolysis reactions were carried out in $5 \mathrm{~mL}$ of $50 \mathrm{mM}$ sodium citrate buffer ( $\mathrm{pH}$ of 4.8 ) with $10 \%$ biomass loading. The glucan content in the solution was maintained at $5 \mathrm{~g}$ glucan per liter. For hydrolysis reactions, $20 \mathrm{mg}$ protein/g glucan of Cellic ${ }^{\circ}$ CTec2 (Novozymes, Davis, CA, USA) and $2 \mathrm{mg}$ protein/g xylan of Cellic ${ }^{\circ}$ HTec2 (Novozymes) were used. To monitor hydrolysis kinetics, $60 \mu \mathrm{L}$ of the supernatant was taken at specific time intervals $(0,0.5,1,3,6,24,48$, and $72 \mathrm{~h})$. The supernatants were centrifuged at $10,000 \mathrm{~g}$ for $5 \mathrm{~min}$, and the released sugars in the supernatant were measured using solutions of D-glucose as calibration standards and high performance liquid chromatography. The untreated Arabidopsis controls were run concurrently with the $140{ }^{\circ} \mathrm{C}$ samples to eliminate potential variances in temperature, humidity, or mixing. The initial rate of hydrolysis was calculated based on the sugar released in the first $30 \mathrm{~min}$ of hydrolysis [10]. The supernatant collected after $72 \mathrm{~h}$ of hydrolysis was analyzed with HPLC for the enzymatic efficiency. All assays were performed with three replicates.

\section{Confocal fluorescence imaging}

Arabidopsis samples from random sections of stem plant with similar diameter were sliced at $100 \mu \mathrm{m}$ with a vibratome (Leica VT1000S, Microsystems Inc. Buffalo Grove, IL, USA). These sections were then stored at $4{ }^{\circ} \mathrm{C}$ until used in the imaging study. Slices were placed between a coverslip and slide with enough $\left[\mathrm{C}_{2} \mathrm{C}_{1}\right.$ im] $[\mathrm{OAc}]$ to wet each sample (about $150 \mu \mathrm{L}$ ) and a thermocouple. The slide was placed in a temperature controlled (LakeShore model 331, Westerville, OH, USA) in-house heater (Advanced Light Source, LBNL). Samples were started at room temperature and ramped to the specified temperature during imaging to using the high heat setting. Samples, on average, reached the specified temperature $\left(70\right.$ or $140{ }^{\circ} \mathrm{C}$ ) before $30 \mathrm{~min}$ and fluctuated \pm $5{ }^{\circ} \mathrm{C}$. Autofluorescent images during heating were collected with a Zeiss LSM 710 confocal system mounted on a Zeiss inverted microscope (Carl Zeiss Microscopy, LLC, Thornwood, NY, USA). Images were collected every 20 to $30 \mathrm{~min}$, and select images are shown (Figs. 3 and 4). A $405 \mathrm{~nm}$ diode laser and a $488 \mathrm{~nm}$ argon laser were used for excitation. Fluorescence emission was collected with a $10 \times$ or $40 \times$ objective and was represented using pseudo colors for three channels: 410 to $469 \mathrm{~nm}$ (blue), 504 to $581 \mathrm{~nm}$ (green), and 592 to $759 \mathrm{~nm}$ (red). The resulting images were analyzed using the Zen software (Carl Zeiss Microscopy) to measure the changes of cell wall thickness.

\section{Statistical analysis}

Statistical analyses were calculated using ProStat (v 5.01, Poly Software International, Pearl River NY, USA). Significance is indicated with the following: $P<0.05^{*}, P<$ $0.01^{* *}, P<0.005^{* * *}, P<0.001^{* * * *}$. Multiple comparisons were done with One-way ANOVA with post-hoc Tukey's HSD. Full results of the statistical analysis can be found in the table and figure legends.

\section{Additional files}

Additional file 1: Movie 1. Confocal fluorescence imaging of WT Arabidopsis during $\left[\mathrm{C}_{2} \mathrm{C}_{1}\right.$ im] $[\mathrm{OAC}]$ pretreatment at $140{ }^{\circ} \mathrm{C}$. Autofluorescence of $100 \mu \mathrm{m}$ slices of the stems from during $\left[\mathrm{C}_{2} \mathrm{mim}\right][\mathrm{OAc}]$ pretreatment at $140{ }^{\circ} \mathrm{C}$ over 3 hours. The temperature ramp from ambient conditions to $140 \pm 5^{\circ} \mathrm{C}$ occurring during time 0 to $46 \mathrm{~min}$. $5 \times$ magnification, 10 frames per second.

Additional file 2: Movie 2. Confocal fluorescence imaging of $L L L$ Arabidopsis during $\left[\mathrm{C}_{2} \mathrm{C}_{1} \mathrm{im}\right][\mathrm{OAC}]$ pretreatment at $140{ }^{\circ} \mathrm{C}$. Autofluorescence of $100 \mu \mathrm{m}$ slices of the stems from during $\left[\mathrm{C}_{2} \mathrm{mim}\right][\mathrm{OAc}]$ pretreatment at $140{ }^{\circ} \mathrm{C}$ over 3 hours. The temperature ramp from ambient conditions to $140 \pm 5^{\circ} \mathrm{C}$ occurring during time 0 to $46 \mathrm{~min}$. $5 \times$ magnification, 10 frames per second.

Additional file 3: Movie 3. Confocal fluorescence imaging of LLHPL 1 Arabidopsis during $\left[\mathrm{C}_{2} \mathrm{C}_{1}\right.$ im $][\mathrm{OAC}]$ pretreatment at $140{ }^{\circ} \mathrm{C}$. Autofluorescence of $100 \mu \mathrm{m}$ slices of the stems from during $\left[\mathrm{C}_{2}\right.$ mim] $[\mathrm{OAC}]$ pretreatment at $140{ }^{\circ} \mathrm{C}$ over 3 hours. The temperature ramp from ambient conditions to $140 \pm 5^{\circ} \mathrm{C}$ occurring during time 0 to $46 \mathrm{~min}$. $5 \times$ magnification, 10 frames per second.

Additional file 4: Movie 4. Confocal fluorescence imaging of LLHPL2 Arabidopsis during $\left[\mathrm{C}_{2} \mathrm{C}_{1} \mathrm{im}\right][\mathrm{OAc}]$ pretreatment at $140{ }^{\circ} \mathrm{C}$. Autofluorescence of $100 \mu \mathrm{m}$ slices of the stems from during $\left[\mathrm{C}_{2}\right.$ mim] [OAc] pretreatment at $140{ }^{\circ} \mathrm{C}$ over 3 hours. The temperature ramp from ambient conditions to $140 \pm 5^{\circ} \mathrm{C}$ occurring during time 0 to $46 \mathrm{~min}$. $5 \times$ magnification, 10 frames per second. 
Additional file 5: Figure S1. Enlarged view of $\left[C_{2} C_{1}\right.$ im] $[O A C]$ pretreatment on Arabidopsis (a, WT, b, LLL, c, LLHPL1, d, LLHPL2) for pretreatment at $140^{\circ} \mathrm{C}$ at 3 hours with temperature increase from ambient to $140 \pm 5^{\circ} \mathrm{C}$ during the first $30 \mathrm{~min}$, scale bar $500 \mu \mathrm{m}$.

Additional file 6: Figure S2. Analysis of confocal imaging of autofluorescence comparing cell wall swelling during $\mathrm{IL}$ pretreatment with $\left[\mathrm{C}_{2} \mathrm{C}_{1} \mathrm{im}\right][\mathrm{OAC}]$ at $70^{\circ} \mathrm{C}$ for 12 hours of $100 \mu \mathrm{m}$ slices from Arabidopsis engineered lines as measured by change of area min normalized to 0 and max normalized to 1. Data shown for 3 individual swelling experiments (two separate experiments on the LLHPL2 engineered line (LLHPL2a and LLHPL $2 b$ and) and one WT). Area was calculated in (ImageJ, NIH). The changing in swelling ends around 5 hours and remains relatively constant for the next 6 hours for all of the lines. 5 hours was chosen as the duration for the pretreatment at $70^{\circ} \mathrm{C}$

Additional file 7: Movie 5. Confocal fluorescence imaging of WT Arabidopsis during $\left[\mathrm{C}_{2} \mathrm{C}_{1} \mathrm{im}\right][\mathrm{OAc}]$ pretreatment at $70{ }^{\circ} \mathrm{C}$. Autofluorescence of $100 \mu \mathrm{m}$ slices of the stems from during $\left[\mathrm{C}_{2} \mathrm{mim}\right][\mathrm{OAc}]$ pretreatment at $70{ }^{\circ} \mathrm{C}$ over 24 hours. The temperature ramp from ambient conditions to $70 \pm 5^{\circ} \mathrm{C}$ occurring during time 0 to $46 \mathrm{~min}$. $5 \times$ magnification, 10 frames per second.

Additional file 8: Movie 6. Confocal fluorescence imaging of LLHPL2 Arabidopsis during $\left[\mathrm{C}_{2} \mathrm{C}_{1}\right.$ im] $[\mathrm{OAc}]$ pretreatment at $70{ }^{\circ} \mathrm{C}$. Autofluorescence of $100 \mu \mathrm{m}$ slices of the stems from during $\left[\mathrm{C}_{2}\right.$ mim] $[\mathrm{OAc}]$ pretreatment at $70{ }^{\circ} \mathrm{C}$ over 24 hours. The temperature ramp from ambient conditions to $70 \pm 5^{\circ} \mathrm{C}$ occurring during time 0 to $46 \mathrm{~min} .5 \times$ magnification, 10 frames per second.

Additional file 9: Tables S1 and S2. Table of Tukey's HSD post-hoc comparison of glucose, xylose or total sugar recovered between the different engineered lines of Arabidopsis versus each other at each pretreatment condition. Table of Tukey's HSD post-hoc comparison of glucose, xylose or total sugar recovered versus pretreatment condition versus the different engineered lines of Arabidopsis.

\section{Abbreviations}

ASR: acid soluble residue; IL: ionic liquid; LLL: low lignin line; LLHPL1: low lignin high polysaccharide lines; WT: wild type Arabidopsis; $\left[\mathrm{C}_{2} \mathrm{C}_{1} \mathrm{im}\right][\mathrm{OAc}]$ : 1-ethyl-3-methylimidazolium acetate.

\section{Competing interests}

The authors declare that they have no competing interests.

\section{Authors' contributions}

CS carried out pretreatment and imaging studies, data analysis, and drafted the manuscript. AC participated in the pretreatment and imaging studies and helped draft the manuscript. DL designed, grew, and harvested the Arabidopsis and helped draft the manuscript. BS, SS, and YC participated in the design of the study and drafting of the manuscript. All authors read and approved the final manuscript.

\section{Acknowledgements}

This work, conducted by the Joint BioEnergy Institute, was supported by the Office of Science, Office of Biological and Environmental Research, of the US Department of Energy under Contract No. DE-AC02-05CH11231.

\section{Author details}

${ }^{1}$ Deconstruction Division, Joint BioEnergy Institute, Lawrence Berkeley National Laboratory, Berkeley, CA, USA. ${ }^{2}$ Biological and Materials Science Center, Sandia National Laboratories, Livermore, CA, USA. ${ }^{3}$ Advanced Light Source, Lawrence Berkeley National Lab, Berkeley, CA, USA. ${ }^{4}$ Feedstocks Division, Joint BioEnergy Institute, Lawrence Berkeley National Laboratory, Berkeley, CA, USA. ${ }^{5}$ Physical Biosciences Division, Lawrence Berkeley National Laboratory, Berkeley, CA 94720, USA. ${ }^{6}$ Joint BioEnergy Institute, 5885 Hollis Street, Emeryville, CA 94608, USA.

Received: 12 August 2014 Accepted: 15 June 2015

Published online: 04 July 2015

\section{References}

1. Blanch HW, Adams PD, Andrews-Cramer KM, Frommer WB, Simmons BA, Keasling JD. Addressing the need for alternative transportation fuels: the Joint BioEnergy Institute. ACS Chem Biol. 2008;3:17-20.

2. Klein-Marcuschamer D, Oleskowicz-Popiel P, Simmons BA, Blanch HW. Technoeconomic analysis of biofuels: a wiki-based platform for lignocellulosic biorefineries. Biomass Bioenerg. 2010;34:1914-21.

3. Searcy E, Flynn P, Ghafoori E, Kumar A. The relative cost of biomass energy transport. Appl Biochem Biotech. 2007;137:639-52.

4. McMillan JD. Pretreatment of lignocellulosic biomass. In: Enzymatic conversion of biomass for fuels production. Volume 566: ACS; 2011: 292-324: ACS Symposium Series.

5. Li C, Cheng G, Balan V, Kent MS, Ong M, Chundawat SP, et al. Influence of physico-chemical changes on enzymatic digestibility of ionic liquid and AFEX pretreated corn stover. Bioresour Technol. 2011;102:6928-36.

6. Stone JE, Scallan AM, Donefer E, Ahlgren E. Digestibility as a simple function of a molecule of similar size to a cellulase enzyme. In: Cellulases and their applications. Volume 95: ACS; 2011: 219-241: Advances in Chemistry.

7. Viamajala S, McMillan JD, Schell DJ, Elander RT. Rheology of corn stover slurries at high solids concentrations-effects of saccharification and particle size. Bioresour Technol. 2009;100:925-34.

8. Arora R, Manisseri C, Li CL, Ong MD, Scheller HV, Vogel K, et al. Monitoring and analyzing process streams towards understanding ionic liquid pretreatment of switchgrass (Panicum virgatum L.). Bioenerg Res. 2010;3:134-45

9. Singh S, Simmons BA, Vogel KP. Visualization of biomass solubilization and cellulose regeneration during ionic liquid pretreatment of switchgrass. Biotechnol Bioeng. 2009;104:68-75.

10. Li CL, Knierim B, Manisseri C, Arora R, Scheller HV, Auer M, et al. Comparison of dilute acid and ionic liquid pretreatment of switchgrass: biomass recalcitrance, delignification and enzymatic saccharification. Bioresour Technol. 2010;101:4900-6.

11. Sun $L$, Li CL, Xue ZJ, Simmons BA, Singh S. Unveiling high-resolution, tissue specific dynamic changes in corn stover during ionic liquid pretreatment. Rsc Adv. 2013;3:2017-27.

12. Han YW, Lee JS, Anderson AW. Chemical composition and digestibility of ryegrass straw. J Agric Food Chem. 1975;23:928-41.

13. Grohmann K, Torget R, Himmel ME. Biotechnol Bioeng Symp. 1985;15:59-80.

14. Huang R, Su R, Qi W, He Z. Understanding the key factors for enzymatic conversion of pretreated lignocellulose by partial least square analysis. Biotechnol Progr. 2010;26:384-92.

15. Chen F, Dixon RA. Lignin modification improves fermentable sugar yields for biofuel production. Nat Biotechnol. 2007;25:759-61.

16. Converse AO, Ooshima H, Burns DS. Kinetics of enzymatic-hydrolysis of lignocellulosic materials based on surface-area of cellulose accessible to enzyme and enzyme adsorption on lignin and cellulose. Appl Biochem Biotech. 1990;24-5:67-73.

17. Blanch HW, Simmons BA, Klein-Marcuschamer D. Biomass deconstruction to sugars. Biotechnol J. 2011;6:1086-102.

18. Van Acker R, Vanholme R, Storme V, Mortimer JC, Dupree P, Boerjan W. Lignin biosynthesis perturbations affect secondary cell wall composition and saccharification yield in Arabidopsis thaliana. Biotechnol Biofuels. 2013;6:46.

19. Eudes A, George A, Mukerjee P, Kim JS, Pollet B, Benke PI, et al. Biosynthesis and incorporation of side-chain-truncated lignin monomers to reduce lignin polymerization and enhance saccharification. Plant Biotechnol J. 2012;10:609-20

20. Thevenin J, Pollet B, Letarnec B, Saulnier L, Gissot L, Maia-Grondard A, et al. The simultaneous repression of CCR and CAD, two enzymes of the lignin biosynthetic pathway, results in sterility and dwarfism in Arabidopsis thaliana. Mol Plant. 2011:4:70-82.

21. Yang F, Mitra $P$, Zhang $L$, Prak L, Verhertbruggen $Y$, Kim JS, et al. Engineering secondary cell wall deposition in plants. Plant Biotechnol J. 2013;11:325-35.

22. Petersen PD, Lau J, Ebert B, Yang F, Verhertbruggen Y, Kim JS, et al. Engineering of plants with improved properties as biofuels feedstocks by vessel-specific complementation of xylan biosynthesis mutants. Biotechnol Biofuels. 2012;5:84

23. Franke R, Humphreys JM, Hemm MR, Denault JW, Ruegger MO, Cusumano $\mathrm{JC}$, et al. The Arabidopsis REF8 gene encodes the 3-hydroxylase of phenylpropanoid metabolism. Plant J. 2002;30:33-45. 
24. Shadle G, Chen F, Reddy MSS, Jackson L, Nakashima J, Dixon RA. Downregulation of hydroxycinnamoyl CoA: shikimate hydroxycinnamoyl transferase in transgenic alfalfa affects lignification, development and forage quality (vol 68, pg 1521, 2007). Phytochemistry. 2007;68:2023-3.

25. Voelker SL, Lachenbruch B, Meinzer FC, Jourdes M, Ki CY, Patten AM, et al. Antisense down-regulation of $4 \mathrm{CL}$ expression alters lignification, tree growth, and saccharification potential of field-grown poplar. Plant Physiol. 2010;154:874-86

26. Mitsuda N, Seki M, Shinozaki K, Ohme-Takagi M. The NAC transcription factors NST1 and NST2 of Arabidopsis regulate secondary wall thickenings and are required for anther dehiscence. Plant Cell. 2005;17:2993-3006.

27. Wu H, Mora-Pale M, Miao J, Doherty TV, Linhardt RJ, Dordick JS. Facile pretreatment of lignocellulosic biomass at high loadings in room temperature ionic liquids. Biotechnol Bioeng. 2011;108:2865-75.

28. Dadi AP, Schall CA, Varanasi S. Mitigation of cellulose recalcitrance to enzymatic hydrolysis by ionic liquid pretreatment. Appl Biochem Biotechnol. 2007;137-140:407-21.

29. Shi J, Gladden JM, Sathitsuksanoh N, Kambam P, Sandoval L, Mitra D, et al. One-pot ionic liquid pretreatment and saccharification of switchgrass. Green Chem. 2013;15:2579-89.

30. Sundin L, Vanholme R, Geerinck J, Goeminne G, Hofer R, Kim H, et al. Mutation of the inducible ARABIDOPSIS THALIANA CYTOCHROME P450 REDUCTASE 2 alters lignin composition and improves saccharification. Plant Physiol. 2014;166(4):1956-71.

31. Vanholme B, Cesarino I, Goeminne G, Kim H, Marroni F, Van Acker R, et al. Breeding with rare defective alleles (BRDA): a natural Populus nigra HCT mutant with modified lignin as a case study. New Phytol. 2013;198:765-76.

32. Vanholme R, Storme V, Vanholme B, Sundin L, Christensen JH, Goeminne G, et al. A systems biology view of responses to lignin biosynthesis perturbations in Arabidopsis. Plant Cell. 2012;24:3506-29.

33. Zhong $\mathrm{R}, \mathrm{Ye} \mathrm{ZH}$. The poplar PtrWNDs are transcriptional activators of secondary cell wall biosynthesis. Plant Signal Behav. 2010;5:469-72.

34. Zhong R, Lee C, McCarthy RL, Reeves CK, Jones EG, Ye ZH. Transcriptional activation of secondary wall biosynthesis by rice and maize NAC and MYB transcription factors. Plant Cell Physiol. 2011;52:1856-71.

35. Chapelle A, Morreel K, Vanholme R, Le-Bris P, Morin H, Lapierre C, et al. Impact of the absence of stem-specific beta-glucosidases on lignin and monolignols. Plant Physiol. 2012;160:1204-17.

36. Eudes A, Liang Y, Mitra P, Loque D. Lignin bioengineering. Curr Opin Biotechnol. 2014;26:189-98.

37. Sluiter A, Hames B, Ruiz R, Scarlata C, Sluiter J, Templeton D. Determination of structural carbohydrates and lignin in biomass. LAP-002 NREL Analytical Procedure. 2008

\section{Submit your next manuscript to BioMed Central and take full advantage of:}

- Convenient online submission

- Thorough peer review

- No space constraints or color figure charges

- Immediate publication on acceptance

- Inclusion in PubMed, CAS, Scopus and Google Scholar

- Research which is freely available for redistribution 